\title{
先進ハードマテリアル
}

\section{高圧合成ダイヤモンドの新展開* \\ Novel Development of High-pressure Synthetic Diamond}

\section{角谷 均** \\ Hitoshi SUMIYA}

Key words synthetic diamond, single crystal, nano-polycrystal, high pressure synthesis

\section{1. は じめに}

宝石の王様と呼ばれ，宝石界のトップに君臨しているダ イヤモンドは，製造業を支える重要な工業材料でもある。 物質の中で最も硬いという特性から，ダイヤモンドは研磨 や研削，切断や切削などの，特に機械加工用工具材として 多量に利用されている。このような工業用に使われるダイ ヤモンドの量は，宝石用途よりも圧倒的に多く，ダイヤモ

\section{ンド全生産量の $98 \%$ を占める.}

この工業用ダイヤモンドの 9 割近くは, 高圧高温条件で 人工的に造られた粉末状の合成ダイヤモンドで，その合成 は 1955 年に GE 社により報告された方法 ${ }^{1}$ がベースとなっ ている。この合成ダイヤモンド粉末は 1960 年代より研磨 材や研削材として実用化され，現在も多量に生産，消費さ れている。また 1970 年ごろから，このダイヤモンド粉末 をCo などの結合材を用いて高圧焼結したダイヤモンド焼 結体が実用化され，切削工具や耐摩工具，掘削ビットなど に利用されている。一方, 1970 年初頭に高圧下の温度差 法による大粒の単結晶ダイヤモンドの育成技術が開発され $た^{223)}$. カラット $(200 \mathrm{mg})$ サイズの宝石級のダイヤモン ドが人工合成できるとのことで当時大きな話題になった が，コストが高すぎ実用化が極めて難しいと考えられた。 しかし，われわれは独自の量産技術を開発して単結晶ダイ ヤモンドの製品化に世界で初めて成功，ヒートシンクや精 密切削工具等に製品化した ${ }^{4)}$. さらに純度や結晶性を大き く向上させる技術を開発し，天然ダイヤモンド結晶を遥か に凌駕する品質を備えた 1 センチ級の大型結晶合成を可能

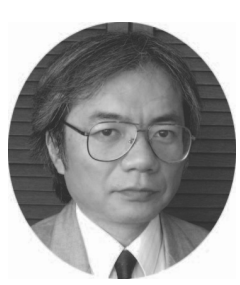

*原稿受付 平成 22 年 9 月 24 日

*正 会 員 住友電気工業 (株)エレクトロニク ス・材料研究所 (兵庫県伊丹市昆陽北 1-1-1) 角谷 均

1984 年大阪大学大学院基礎工学研究科修士課程 修了. 同年, 住友電気工業 (株) 伊丹研究所勤 務. 博士 (工学). 現在, 住友電気工業 (株) 工 レクトロニクス・材料研究所主幹, グループ 長. 大阪大学および愛媛大学客員教授. 主な研 究テーマは, ダイヤモンド・cBN の超高圧合成の研究とその応用製品の開 発, 超高圧を用いた新材料開発。
にした。この良質な大型合成ダイヤモンド単結晶は光学部 品や大型放射光用分光結晶, 電子デバイス基板など，先端 科学や研究用途にも広く利用されている ${ }^{5)}$. また最近, 触 媒や溶媒を用いない, グラファイトからの直接変換による ダイヤモンド合成法を発展させ, ダイヤモンド単相の高硬 度ナノ多結晶体の開発に成功した。このナノ多結晶ダイヤ モンドは次世代の精密加工用工具素材として期待されてい $3^{6777}$ 。このように, 特にこの十数年間はダイヤモンド合 成技術に大きな進展が見られ, 粉末の合成ダイヤモンドや それを固めた砥石や焼結体などの古兵のダイヤモンド材料 に加えて, 大型で高結晶性の単結晶, バインダレスの超硬 質ナノ多結晶といった，新規な合成ダイヤモンドが創出さ れた。これらの一部はすでに実用化されて産業や科学技術 の発展に貢献している

現在知られているダイヤモンドの合成方法と，それによ り得られるダイヤモンドの形態，応用例を図 1 にまとめ た，合成方法は大きく高圧合成，CVD 合成に分けられる。 ここでは，超高圧力を用いた各種合成方法（溶解度差法, 温度差法, 直接変換法）の技術の概要を述へ，特に上記の ニューダイヤモンドの創製と新展開に関し，われわれが行 ってきた研究開発を中心に紹介する。

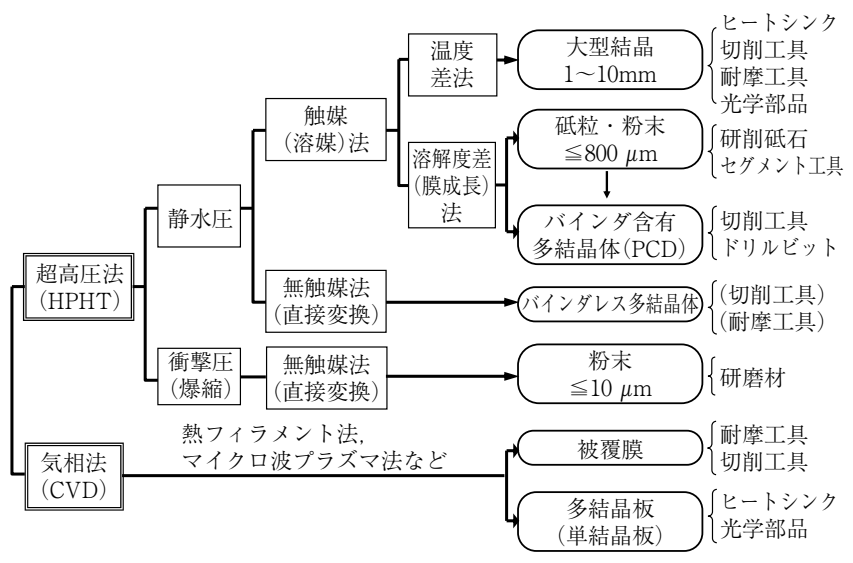

図 1 ダイヤモンドの合成方法と形態, 応用例 


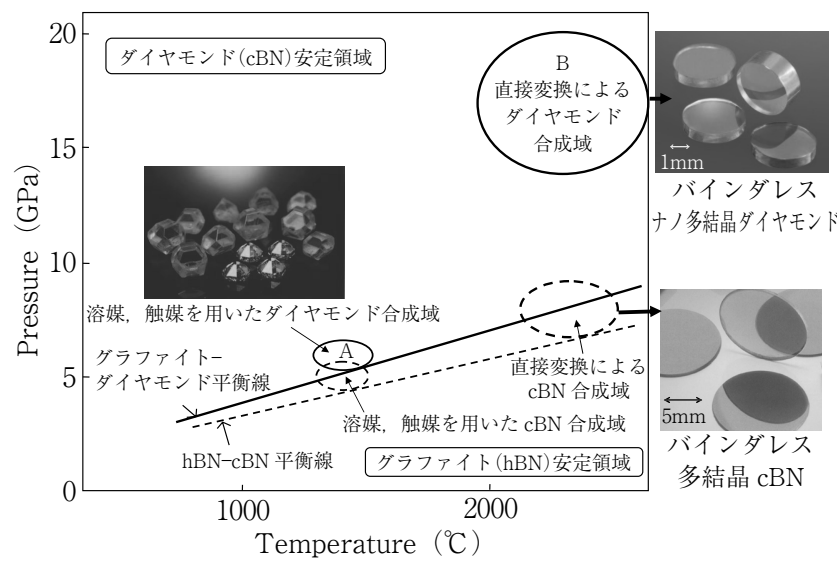

図 2 ダイヤモンドの合成域. 比較のため $\mathrm{cBN}$ の合成域もあわせて 示す.

\section{2. 合成ダイヤモンド粉末とダイヤモンド焼結体 (PCD)}

ダイヤモンドが初めて合成されたときに用いられた方法 は，ここで述べる超高圧下での溶解度差法である。グラフ アイトと, $\mathrm{Fe}, \mathrm{Ni}, \mathrm{Co}$ などの溶媒（触媒）金属を混合ある いは積層して, ダイヤモンドが熱力学的に安定な圧力で, グラファイトが溶媒金属に溶解する温度以上の条件（およ そ $5.5 \mathrm{GPa}$ 以上, $1400^{\circ} \mathrm{C}$ 以上. 図 2 の A で示す領域）で 処理すると，グラファイトが金属溶媒に溶解し，溶解度が グラファイトより小さいダイヤモンドが析出する。この方 法で，数十分の処理で $1 \mathrm{~mm}$ 以下の粉末状のダイヤモンド を容易に多量に合成することができる。この合成ダイヤモ ンド粉末は，研磨材あるいは研削砥石やカッティングソー などの砥粒として大量に使用されている。これらの合成夕゙ イヤモンド粉末を用いたダイヤモンド工具製品の国内生産 額は年間約 5 百億円に上る（ダイヤモンド工業協会データ より).

この粉末状の合成ダイヤモンドを，焼結助剤や結合材 (バインダー) を用いて高圧高温下で焼き固めた焼結ダイ ヤモンド $(\mathrm{PCD})$ も, 非鉄金属や七ラミックスの切削工 具，掘削用ドリルビットなどとして広く利用されている. 現在市販されている焼結ダイヤモンドの多くは，Co なと の触媒金属を焼結助剤とした液相焼結法により製造されて いる，粒径や焼結助剂量の異なる幾つかの材質があり，そ れぞれ刃先強度や耐摩耗性に特徵があって用途によって使 い分けられている。最近では製造装置の大型化により，直 径 $100 \mathrm{~mm}$ を超える大径の焼結ダイヤモンドが製造可能と なっている。

\section{3. 合成技術の新展開}

\section{1 大型単結晶ダイヤモンドの実用化}

前章で述べたグラファイトを原料とした溶解度差法は, 粉末状のダイヤモンドを多量に合成することができるが, ダイヤモンドの自核発生や成長速度の制御が困難で，グラ

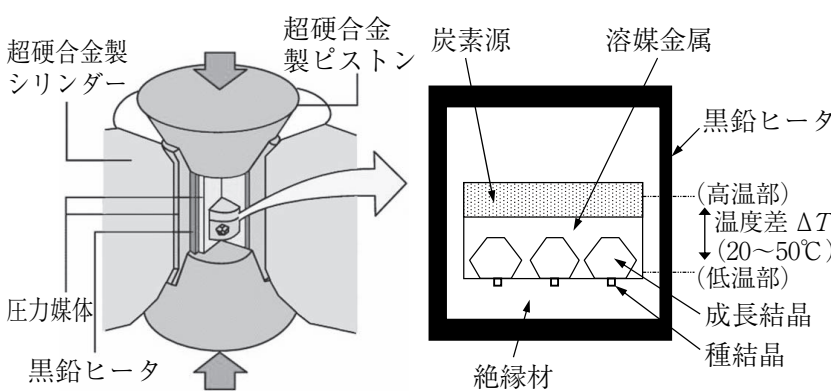

図 3 大型単結晶ダイヤモンドの合成方法（高圧下での温度差法）

ファイトや金属触媒巻き込みによる包有物が残りやすく, $1 \mathrm{~mm}$ を超える良質な単結晶合成は不可能である。大型で 良質な単結晶ダイヤモンドの合成には，ここで述べる温度 差法 ${ }^{23)}$ が有効である．図３に示すような高温部に炭素源, 低温部に種結晶，その間に $\mathrm{Fe} ， \mathrm{Ni} ， \mathrm{Co}$ などの溶媒金属を 配した合成室構成で，図 2 の A に示す圧力・温度条件を 与える。すると, 高温部で炭素が溶媒金属に溶解し, 溶媒 下方の低温部に拡散輸送されて過飽和となり，種結晶上に ダイヤモンド析出し，単結晶となって成長していく，ここ で適切な圧力温度条件を長時間保持すれば，一辺が数ミリ 以上の大型で，かつ包有物のない良質な単結晶の合成が可 能である。ただし，この方法は，粉末ダイヤモンドの合成 に比べて，はるかに高い超高圧高温制御技術が必要で ある.

この温度差法が発表された当初は，良質な結晶を得るた めには, 成長速度を $1 \mathrm{mg} / \mathrm{h}$ 前後以下と低く抑える必要が あり，例えば 1 カラット（大きさ $5 \mathrm{~mm}$ 程度）の合成に一 週間を要するとされた ${ }^{2)}$ 。このため，製造コストが高す ぎ，また生産性にもそしく，実用化は困難と考えられてい た。これに対してわれわれは，より適切な溶媒の選択と合 成条件の最適化により, 良質な結晶の得られる限界成長速 度を $4 \mathrm{mg} / \mathrm{h}$ まで向上させるとともに, 超高圧高温の精度 制御の高度化と試料室容積の大型化, 多段合成による量産 技術を開発した。 そして 1985 年，1２ 2 カラットの単結晶 ダイヤモンド（Ｉｂ型）の量産化に成功，ヒートシンク や超精密バイト, 線引きダイス, ドレッサーなどに製品化 した ${ }^{4)}$ 。さらに 1990 年には種結晶の大径化と結晶形制御 技術 ${ }^{8}$ により，成長速度を $12 \sim 15 \mathrm{mg} / \mathrm{h}$ まで向上させるこ とにも成功，100〜200 時間で 5〜9 カラットの一辺 $1 \mathrm{~cm}$ を超える大型結晶（図4）の合成を可能にした。

\section{2 高品質単結晶ダイヤモンドの開発}

通常，高圧合成されたダイヤモンドの結晶は黄色く着色 している。この色は, ダイヤモンドの結晶格子に, 置換型 で取り込まれている窒素不純物によるもので, 反応セルや 溶媒中に含まれている窒素が原因である。このような黄色 い合成ダイヤモンドは I b 型と呼ばれており，含まれる 窒素不純物量は数十 $\mathrm{ppm}$ から数百 $\mathrm{ppm}$ である。この窒素 不純物の混入を防ぐには, 窒素と親和性の高い $\mathrm{Al}, \mathrm{Ti}, \mathrm{Zr}$ などの元素を溶媒に添加する方法が有効である。しかし， 


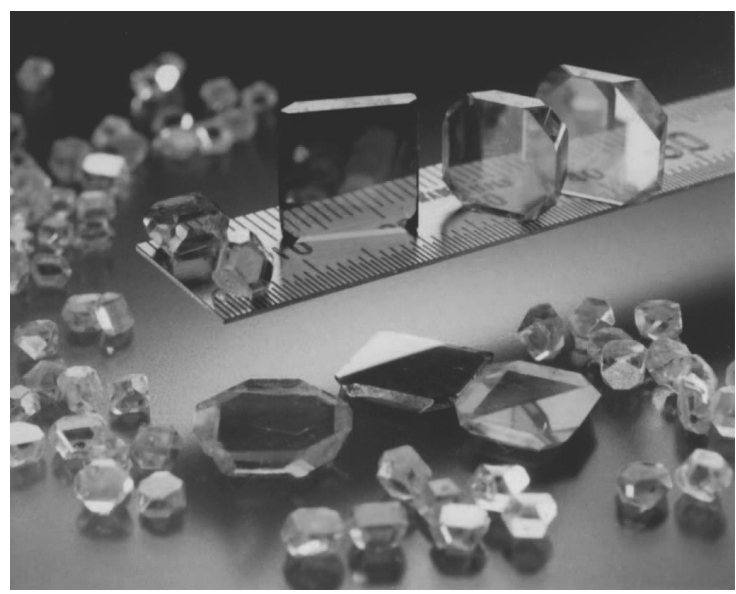

図 4 大型合成 I b 型ダイヤモンド単結晶（グラビアページ参照）

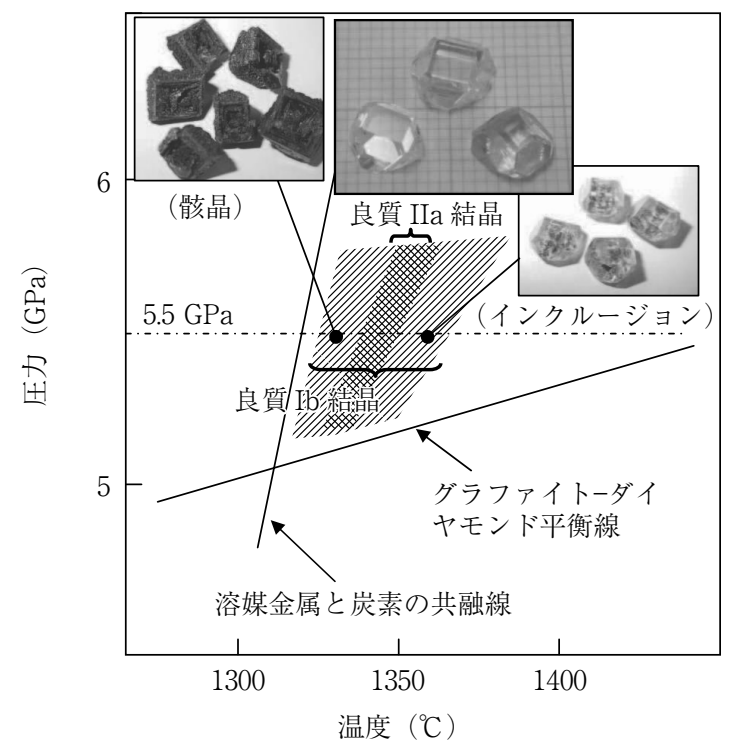

図 5 良質な単結晶ダイヤモンドの得られる領域

このような元素を溶媒に添加すると，結晶成長が不安定と なって溶媒の巻き込みや骸晶化，炭化物の混入などの不具 合が起こり，良質な結晶は得られない。この理由で, 高純 度で無色透明のII a 型と呼ばれるダイヤモンド単結晶の実 用化は極めて困難とされていた。

われわれは，窒素除去効率の高い Ti などの IV a 族元素 を窒素ゲッターとして用い, 同時に TiC などの炭化物の 生成を抑制する元素を添加する新しい方法を開発した。そ の結果，窒素不純物含有量 $0.1 \mathrm{ppm}$ 以下の高純度で良質な II a 型ダイヤモンド単結晶を, $3 \mathrm{mg} / \mathrm{h}$ 以上の成長速度で 合成できることを実証した ${ }^{9)}$ 。ただし，温度制御が極めて 重要で，図 $5^{8)}$ に示すように良質な結晶が得られる温度領 域の幅は $10^{\circ} \mathrm{C}$ 以内で, 黄色い I b 型結晶の合成領域 (30 40ㄷ) に比べ, 非常に狭い.このため, さらに高度 な圧力温度の制御技術の開発が必要となった。このような 技術開発により，従来極めて困難とされていたII a 型の高 純度合成単結晶ダイヤモンドの実用化がようやく可能とな
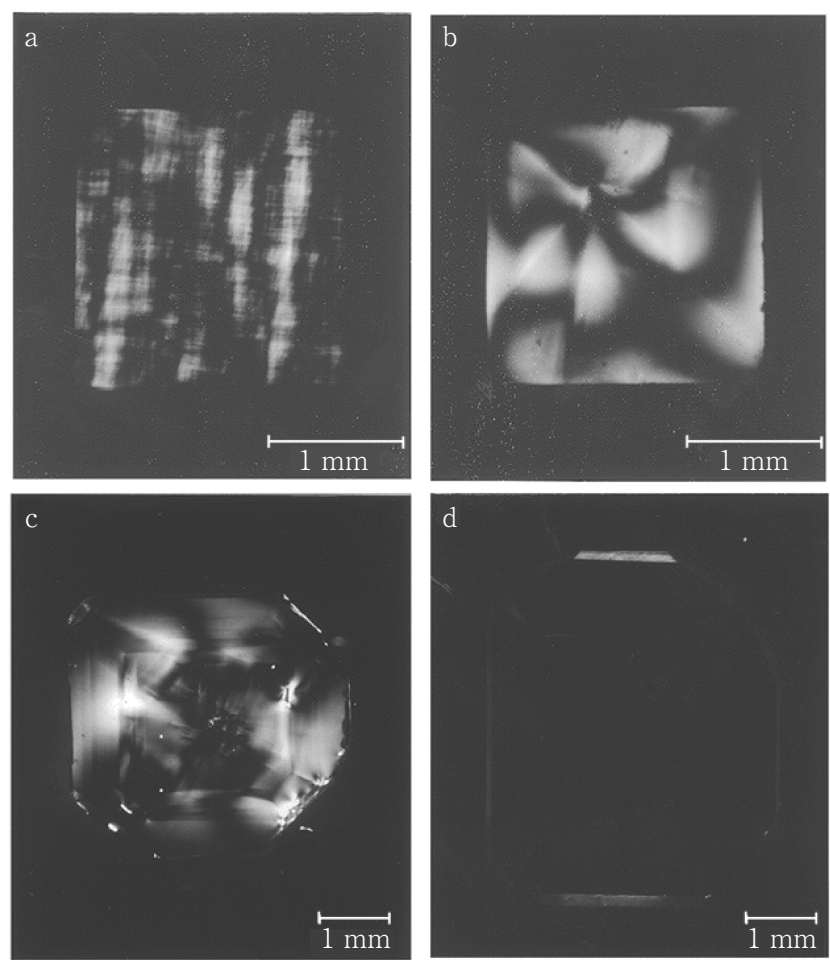

図 6 各種単結晶ダイヤモンドの偏光顕微鏡像 ${ }^{10)}$

（a）天然 II a 型，（b）天然 I a 型，（c）合成 I b 型，（d）合 成 II a 型

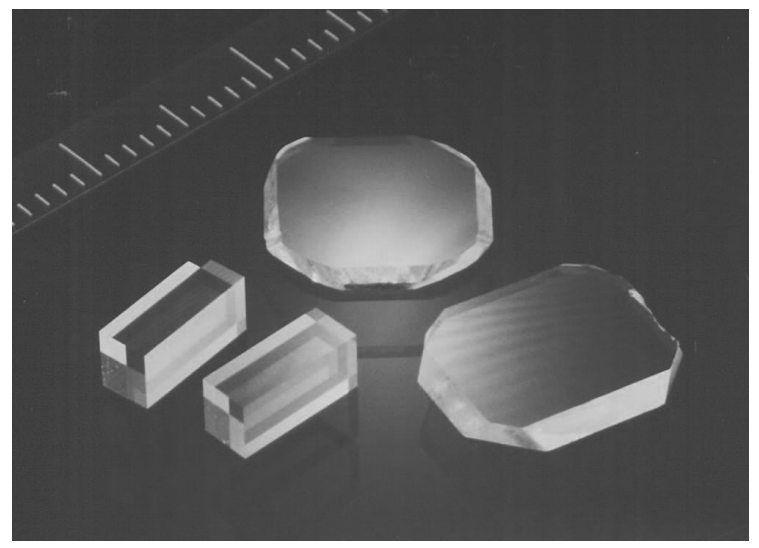

図 7 温度差法により得られた高純度 II a 型単結晶ダイヤモンド (グラビアページ参照)

った.この II a 型合成結晶は, 天然ダイヤモンドや従来の I b 型ダイヤモンドに比べてはるかに結晶性に優れてい る。例えば図 6 に示すように内部歪はほとんどなく，X 線やラマンスペクトルによる欠陮評価においても, 天然ダ イヤモンドや従来の I b 型合成ダイヤモンドに比べ，は るかに結晶欠陥が少ないことがわかっている ${ }^{10)}$.さらに種 結晶の結晶性向上により, さらに結晶欠陥の少ない高品質 な大型II a 型単結晶ダイヤモンドも得られるようになって いる $(\text { 図 7 })^{6)}$ 。この合成単結晶は, FT-IR 用加圧セル (グラビア写真参照) などの赤外光学部品や空材の他, 大 型放射光用の分光結晶や超高圧アンビル, デバイス基板な ど，工業から科学の広範な分野で利用されている。ここで 
述べた高品質な合成単結晶ダイヤモンドは, 今後の工業や 科学技術の発展をささえる重要な材料と位置づけることが でき, 各技術分野の多様化・高度化に伴って, その重要性 は将来さらに増すものと考えられる。

\section{3 直接変換法によるナノ多結晶ダイヤモンド}

現在, 工業生産されている合成ダイヤモンドのほとんど は，ここまでに述べた触媒や溶媒を用いた方法により， 5 6 GPa， $1300 \sim 1400^{\circ} \mathrm{C}$ 程度の高圧高温条件で製造され ている，一方，触媒を用いずに，黒鉛を高圧・高温下で直 接ダイヤモンドに変換させることもできる。 ただしこれに は，触媒を用いる方法に比べてかなり高い圧力条件（図 2 のB）が必要とされる ${ }^{11}$ ．黑鉛がダイヤモンドに変換開始 する温度条件は圧力によって異なるが, 例えば $15 \mathrm{GPa}$ で は $1500^{\circ} \mathrm{C}$ 前後よりダイヤモンドへの変換が始まり, $2200 \sim 2300^{\circ} \mathrm{C}$ 以上でダイヤモンドに完全変換する。 ここ で，変換と同時に焼結させて取り出すと，図 8 に示すよ うな透光性を有するダイヤモンド単相（バインダレス）の 多結晶体が得られる ${ }^{612)}$ ，われわれは，この直接変換によ

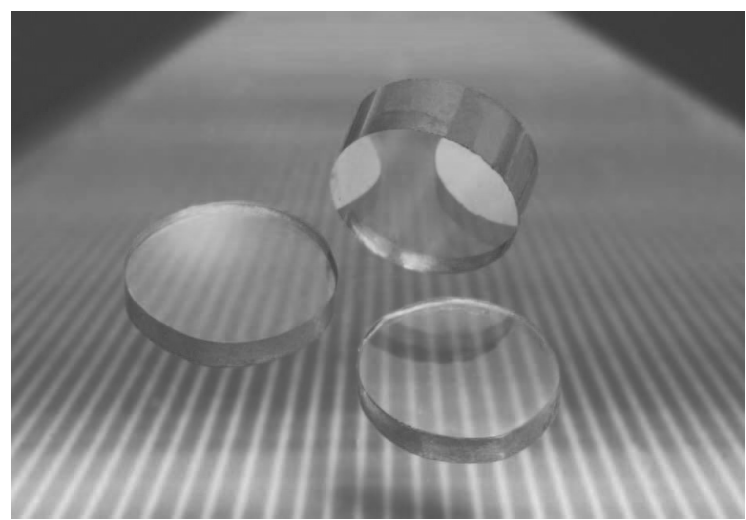

図 8 直接変換法により得られたナノ多結晶ダイヤモンド（グラビ アページ参照)
る多結晶ダイヤモンドは，図 9 に示すように数十ナノメ 一トルの非常に微細な粒子からなること ${ }^{13)}$, 出発物質や合 成条件によっては図 10 に示すような単結晶ダイヤモンド を凌駕する硬さのものが得られることを明らかにした ${ }^{14)}$. この多結晶ダイヤモンドは，非常に高い硬度を有するとと もに, 単結晶のような擘開性がなく, 耐熱性にも優れてい る.このため, 切削工具や耐摩工具として高いポテンシャ ルを有して抢り ${ }^{7)}$, 次世代の硬質材料として大きな展開が 期待される. 開発当初は $1 \mathrm{~mm}$ 以下の小さく, 亀裂や欠陥 のある試料であったが, 最近は $8 \mathrm{~mm}$ サイズの高品質で均 質なナノ多結晶ダイヤモンドが得られるようになり，実用 化も近く可能であると考えている。

なお, 同様の直接変換プロセスで, cBN（立方晶窒化木 ウ素) 単相のバインダレス cBN 多結晶体も得られる（図 2 に合成域を点線で示す)。ここでは詳細は述べないが, 従来の cBN 焼結体に比べ優れた特性を示すことがわかっ ており ${ }^{15)}$ ，われわれはその実用化も検討している.

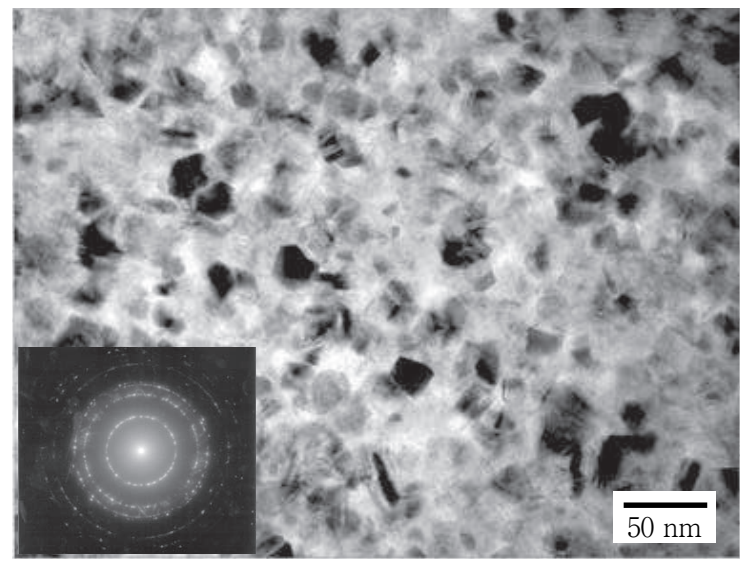

図 9 ナノ多結晶ダイヤモンドの透過電子顕微鏡写真

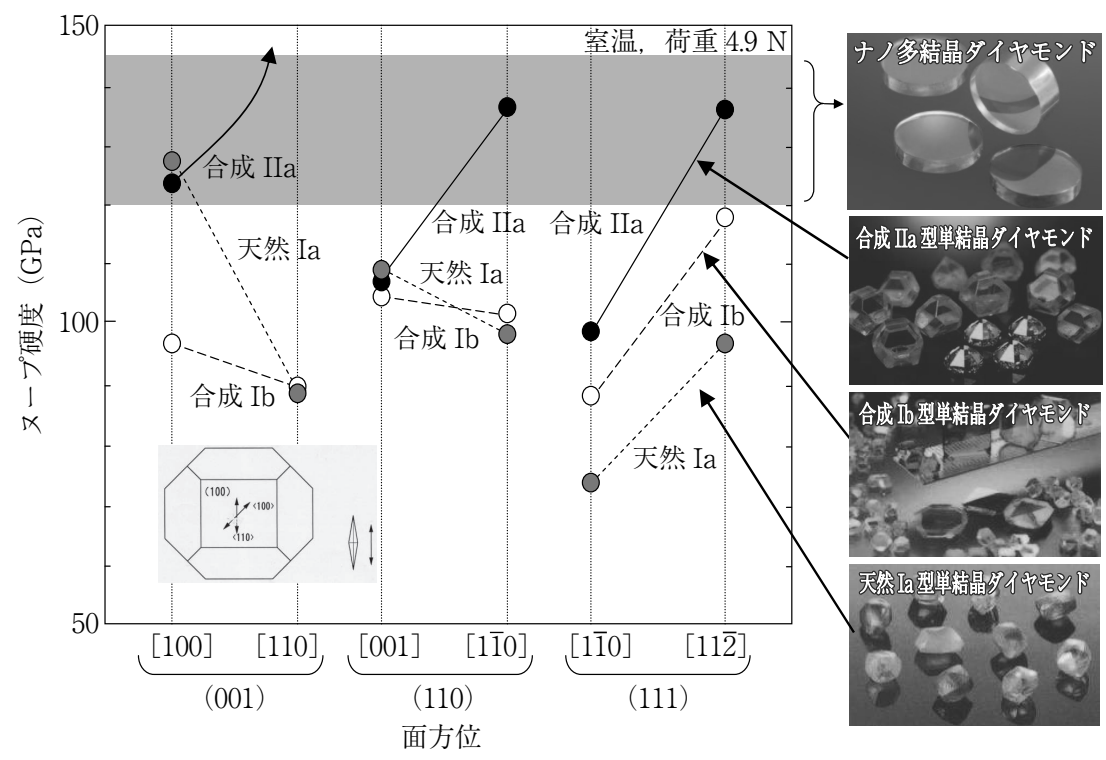

図 10 ナノ多結晶ダイヤモンドと単結晶ダイヤモンドのヌープ硬度 


\section{4. おわりに}

近年めざましい機械加工の高精度化と高能率化，そして 加工素材の多様化，難削化に対応できる工具材料の要とな るのは材料の王様でもあるダイヤモンドである。機械加工 工具として合成ダイヤモンドに寄せられる期待は今後さら に大きくなると思われる，特に精密加工用途においては， 本稿で述べた高品質単結晶ダイヤモンドや高硬度ナノ多結 晶ダイヤモンドに大きな期待が寄せられている.

ダイヤモンドは硬さや強度などの機械的な特性が卓越し ているだけでなく, 熱伝導性, 電気特性, 光学特性, 表面 化学特性にも非常に優れる。大型で高品質な合成単結晶夕゙ イヤモンドの実用化の成功により，これらの機械的特性以 外のダイヤモンドの優れた性質を十分活用することが可能 になり，それまで，削ったり切ったりの道具でしかなかっ たダイヤモンドが，光学部品や電子部品などの新用途への 展開を具現化し始めている。また，合成ダイヤモンドは特 性を人為的に改善・制御でき，新たな機能を付加すること も可能で，さらに新たな分野への展開も期待できる.

\section{参 考 文 献}

1) F.P. Bundy, H.T. Hall, H.M. Strong and R.H. Wentorf, Jr. : Nature, 176 (1955) 51

2) R.H. Wentorf, Jr: J. Phys. Chem., 75 (1971) 1833.

3) H.M. Strong and R.M. Chrenko : J. Phys. Chem., 75 (1971) 1838.

4）原昭夫：精密機械, 51（1985） 1497.

5）角谷均, 戸田直大, 佐藤周一：SEI テクニカルレビュー, 166 (2005) 7.

6）角谷均，入舩徹男：SEI テクニカルレビュー，172（2008） 82

7）原野佳津子, 佐藤武, 角谷均, 久木野暁 : SEI テクニカルレビ ユー, 177 (2010) 107.

8) H. Sumiya, N. Toda and S. Satoh: J. Crystal Growth, 237-239 (2002) 1281.

9) H. Sumiya and S. Satoh: Diam. Relat. Mater., 5 (1996) 1359.

10) H. Sumiya, N. Toda, Y. Nishibayashi and S. Satoh: J. Crystal growth, 178 (1997) 485.

11) F.P. Bundy : J. Chem. Phys., 38 (1963) 631

12) T. Irifune, A. Kurio, S. Sakamoto, T. Inoue and H. Sumiya : Nature, 421 (2003) 599

13) H. Sumiya, T. Irifune, A. Kurio, S. Sakamoto and T. Inoue : J. Mater. Sci., 39 (2004) 445.

14) H. Sumiya and T. Irifune : Diam. Relat. Mater., 13 (2004) 1771.

15）角谷均, 上坂伸哉：NEW DIAMOND, 15, 4 （1999） 14. 